\title{
Role of public participation in sustainability of historical city: usage of TOPSIS method
}

\author{
Ali Assari ${ }^{1 *}$, T.M. Maheshand ${ }^{2}$ and Erfan Assari ${ }^{1}$ \\ ${ }^{1}$ Department of Civil Engineering, Isfahan Sciences and Research Branch, Islamic Azad University, Isfahan, Iran \\ ${ }^{2}$ Institute of Development Studies, University of Mysore, Manasagangotri, Mysore-570 006, Karnataka State, India \\ *ali_assari1358@yahoo.com
}

\begin{abstract}
It is clearly known that support and participation of public and social groups is essential to the achievement of sustainable development in historical city. In this case, public participation and heritage awareness facing the historical cities and analyzing them is of the first useful step. In this research article we try to find out the parameters that affect sustainable development in heritage area and relationship among them (in public point of view). We also ranked these parameters. TOPSIS was demonstrated as a model for selection and ranking of strategic plans in Balanced Scorecard and Goal Programming model. The results of this study revealed that the social side of sustainable development has more weightage compared to economic and environment aspect. Parking space and traffic, historical environment in new design, air and sound pollution are the three most important indicators.
\end{abstract}

Keywords: Sustainable development, public participation, TOPSIS, heritage awareness, PIS, NIS. Introduction

During the recent decades, issues related to sustainability of historical city have tied to topics and theories in terms of participation of whole citizens in the city. It is widely accepted that sustainable development of cities greatly depends on the functions of public participation.

Sustainable development is development that meets the needs of the present without compromising the ability of future generations to meet their own needs (World Commission on Environment \& Development, 1987). Francois Jegou \& Ezio Manzini (2004) states that, the first guideline for sustainable development in historical cities is use which already exists. And the conservation of built heritage is a priority in any sustainable development framework (Doratli, 2004).

Public participation is currently regarded as a key to conflict resolution and sustainable development (Sirisrisak, 2009). The rise of public participation in city development could be seen through written works since the 1940s by some notable contributors such as Kurt Lewin, Patrick Geddes, and Lewis Mumford (Fisher, 2001). It is widely accepted that sustainable development of cities depends greatly on the functions of public participation (Azman et al., 2010). The success of heritage conservation and development in historical city mainly depends on two set of factors: 1) Awareness, participation and appreciation towards heritage values and its economic potential; 2) Education programmes designed for each historical cities (Assari et al., 2011).

\section{Charters and ethics for historical cities}

The public participation concept was included in the Washington charter for the conservation of historic towns, adopted in 1987 by ICOMOS, which emphasized that "The participation and the involvement of the residents are essential for the success of the conservation program and should be encouraged. The conservation of historic towns and urban areas concerns their residents first of all". Brazilian Seminar about the Preservation and Revitalization of Historic Centers defines: The preservation of urban historical sites demands the integrated action of federal, state and local entities, and also the participation of the community concerned with planning decisions as part of the full exercise of citizenship (ICOCOMOS, 1987).

For public awareness in 12th General Assembly ICOMOS in Mexico 1999 emphasized that "Interpretation and presentation programmes should facilitate and encourage the high level of public awareness and support necessary for the long term survival of the natural and cultural heritage" (ICOMOS, 1999). The education and sensitization for conservation should begin in schools and continue in universities and beyond. These institutions have an important role in raising visual and cultural awareness - improving ability to read and understand the elements of our cultural heritage - and giving the cultural preparation needed by candidates for specialist education and training.

Practical hands-on training in craft work should be encouraged (ICOMOS,1993). European charter of the architectural heritage define: The public should be properly informed because citizens are entitled to participate in decisions affecting their environment. Each generation has only a life interest in this heritage and is responsible for passing it on to future generations (European Charter of the Architectural Heritage,1975) and totally integrated conservation cannot succeed without the cooperation of all (European Charter of the Architectural Heritage, 1975).

Definition of historical city in Iran

Each historic city in Iran should be an organic and alive system that its form and function have direct effect on human's attitude and behavior (Tavasoli, 2002). According to Abdi \& Namin (2008) the following classification could be suggested for historical city in Iran: 1. Cities with single heritage or monument (containing the monument and building which has remained from the
Research article

(C)Indian Society for Education and Environment (iSee)
"TOPSIS in heritage conservation in Iran" http://www.indjst.org
A.Assari \& E.Assari Indian J.Sci.Technol. 
past) as: a) Heritage out of city boundary b) Heritage within the city boundary.

2. Cities with historical areas (it should be mentioned that in many cases inappropriate physical-oriented policies have caused deterioration and obliteration in such areas). 3. Cities with multi historical heritage sets (most of historical heritage sets in Iran are from a specific era but in some cases, expansions like Bazaar \& religious centers were added to them later (Assari et al., 2011).

Sustainability of historic city is an integral of economic, social, and environmental considerations. Sustainable urban heritage is a kind of changing in city structure that attempts to invent new solution which has balance with environment, social and economic purposes (Tavakoli, 2010).

For sustainable development in historical city all important and effective elements in fields of urban sustainability should be analyzed (Assari \& Assari, 2012). For this reason the most principal indicators of sustainable city are classified in Fig. 1 that was prepared as a questionnaire. Thereafter, the main factors of sustainability were demonstrated in Iranian historical cities.

Fig. 1.Sustainable development in historical cities in iran

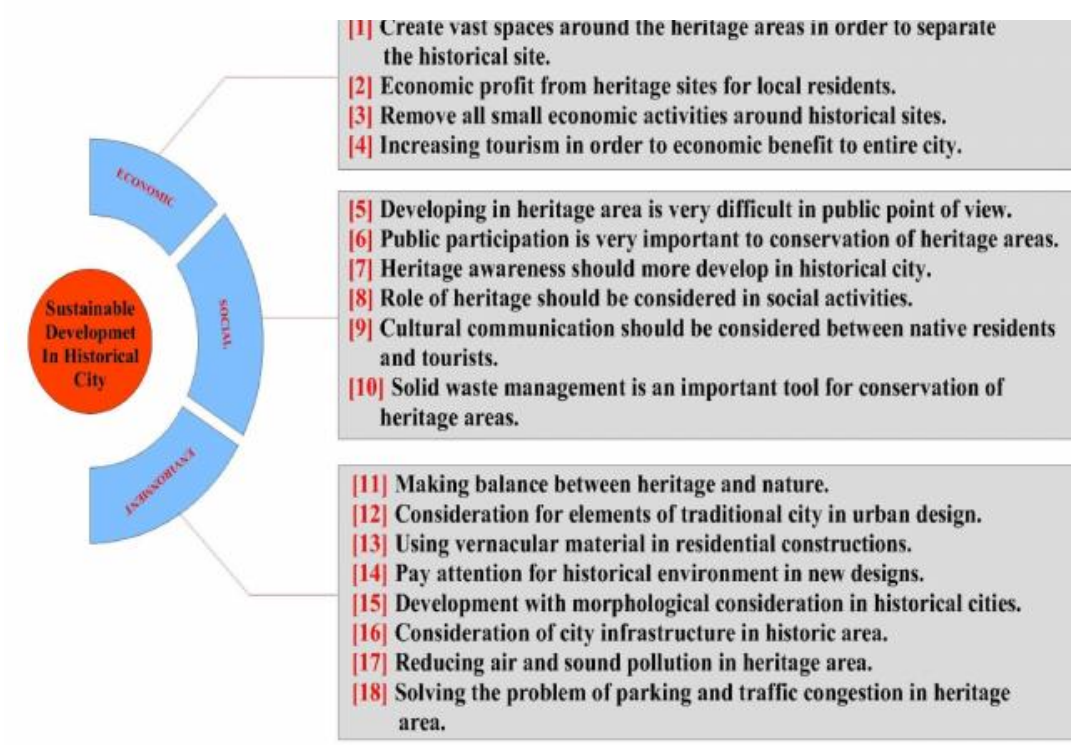
method.

The sample reviewed 70 cases of heritage society who are the resident in historical area of Isfahan; the reliability (alpha cronbach) is 0.817 in this questionnaire, and random selection and data was analyzed by TOPSIS

\section{TOPSIS (Technique for Order-Preference by Similarity to} Ideal Solution)

TOPSIS is one of the useful Multi Attribute Decision Making techniques, which is very simple and easy to implement, so that it is used when the user prefers a simpler weighting approach (Ball \& Korukoğlu, 2009). It was firstly proposed by Hwang and Yoon (1981). According to this technique, the best alternative would be the one that is nearest to the positive ideal solution and farthest from the negative ideal solution (Asgharpour, 1999; Benitez et al., 2007).

The positive ideal solution is a solution that maximizes the benefit criteria and minimizes the cost criteria, whereas the negative Ideal solution maximizes the cost criteria and minimizes the benefit criteria. TOPSIS method can be used with both normal numbers and fuzzy numbers. It is a method for ranking the parameters and in this article writers uses it to rank all the affective parameters on role of public participation on sustainable development which were about 18 parameters that collected from people who lives in heritage area in Isfahan city (Fig.2). The method is calculated as follows:

Step 1.Decision matrix is normalized via Eq. (1):

$$
\boldsymbol{n i j}=\frac{\mathrm{rij}}{\sqrt{\sum_{\mathrm{i}=1}(\mathrm{rij})^{2}}}
$$

nij: stands for the score of each parameter which has been none scaled.

rij : is stands for utility of each parameter.

$\mathrm{i}=$ number of question (1 to 18)

$\mathrm{j}=$ rank of question (1 to 5 )

Step 2.Weighted normalized decision matrix is formed:

$\mathrm{V}=\mathrm{N}_{\mathrm{d}}{ }^{*} \mathrm{~W}_{\mathrm{n}, \mathrm{n}}$

$V$ : stands for the none scaled weight matrix

\section{Methodology}

The research methodology of this article was designed that is how to rank all the affected parameters on sustainability of historic city by help of technique for order preference by similarity to ideal solution (TOPSIS).

In this research, questionnaire method used for collecting primary data was prepared based on literature review and the problem faced by the historical city in Iran. It had five options (index) ranked 1-5 for the raised questions that could be found as follows: $\mathrm{NI}=$ not important $\mathrm{LI}=$ low important $\mathrm{A}=$ average $\mathrm{I}=$ important $\mathrm{VI}=$ very important.
Step 3. Positive ideal solution (PIS) and negative ideal solution (NIS) are determined:

$P I S=A+=\left\{\left(\max V_{i j}\right),\left(\max V_{i j}\right), i, j=1,2, . . m\right\}=\left\{V_{1+}, V_{2+}, \ldots V_{n+}\right\}(3)$

NIS $=A-=\left\{\left(\min V_{i j}\right),\left(\min V_{i j}\right), i=1,2, \ldots, m\right\}=\left\{V_{1-}, V_{2-}, \ldots V_{n}-\right\}$

Step 4. The distance of each alternative from PIS and NIS are calculated:

$$
\begin{aligned}
& D_{-}=\sqrt{\sum_{j=1}(v i j-v j-)^{\wedge} 2} \\
& D+=\sqrt{\sum_{j=1}(v i j-v j+)^{\wedge} 2}
\end{aligned}
$$

Step 5. The closeness coefficient of each alternative is 


\section{Fig. 2. Sustainable development of historical} city in public point of view

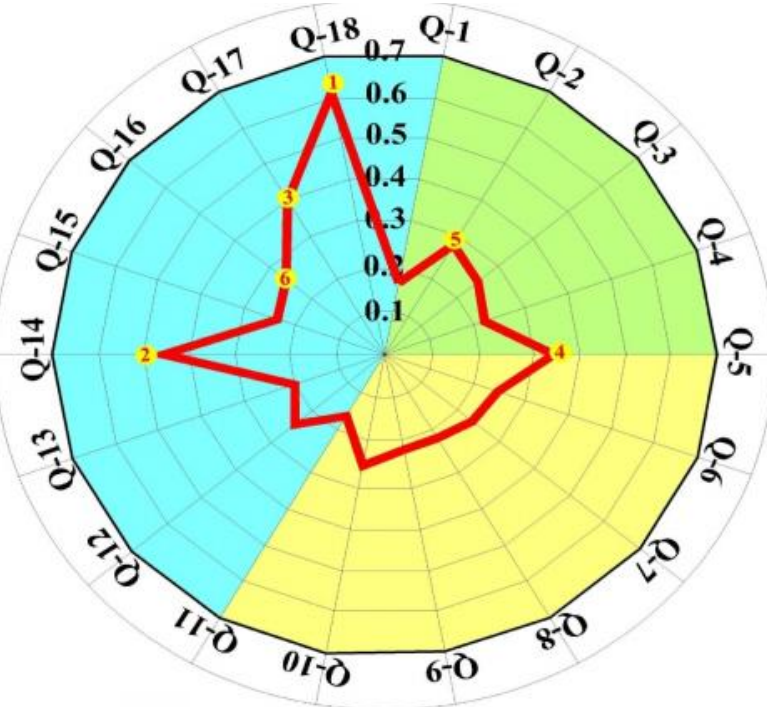

calculated:

$\mathrm{C}_{\mathrm{li}+}=\frac{\mathrm{Di}_{-}}{(\mathrm{Di}+)+(\mathrm{Di}-)}$

Step 6. By comparing $\mathrm{C}_{\mathrm{li}}$ values, the ranking of alternatives are determined.

Table 1 presents the result of questionnaire

$$
n i j=\frac{\mathrm{rij}}{\sqrt{\sum_{\mathrm{i}=1}(\mathrm{rij})^{2}}}
$$

Table 2 provides the first process on the result of questionnaire by multiply each cell by itself and second process each cell should divided to sqrt

$n 1,1=\frac{9 * 9}{\sqrt{228}}=5.36$,

$n 1,2=\frac{11 * 11}{\sqrt{583}}=5.01, n 1,3=\frac{15 * 15}{\sqrt{7264}}=2.64, n 1,4=$

$\frac{26 * 26}{\sqrt{9415}}=6.97, n 1,2=\frac{9 * 9}{\sqrt{10877}}=0.78$

Matrix 3: the matrix of weight that were calculated SQRT/ SUM (SQRT)

$\mathrm{W}_{\mathrm{n}, \mathrm{n}}=\frac{\mathrm{SQRT}}{\text { SUM (SQRT) }} \quad \mathrm{W}_{1,1}=\frac{15.10}{325.8}=0.046 \quad \mathrm{~W}_{2,2}=\frac{24.15}{325.8}=$

$0.074 \quad W_{3,3}=\frac{85.23}{325.8}=0.262$

$W_{4,4}=\frac{97.03}{325.8}=0.298 \quad W_{5,5}=\frac{104.29}{325.8}=0.320$

$\left[\begin{array}{ccccc}0.046345 & 0 & 0 & 0 & 0 \\ 0 & 0.074112 & 0 & 0 & 0 \\ 0 & 0 & 0.2616 & 0 & 0 \\ 0 & 0 & 0 & 0.297823 & 0 \\ 0 & 0 & 0 & 0 & 0.320113\end{array}\right]$

Table 3 represents the matrix of multiply of tables 2 by matrix 3.

Table 4 presents the max and min of each column in Table 3 that highlighted with red and blue color.
Vol. 5 No. 3 (Mar 2012)

ISSN: 0974- 6846

Table 5 represents the forth step in TOPSIS method (it has five parts)-distance between max point and each point.

Table 6 represents the forth step in TOPSIS method (it has five parts)-distance between min point and each point.

\section{Result and findings}

Table 7 shows the last part of normal TOPSIS with about 18 affected parameters on sustainability of historical city (in public point of view) and also about 70 cases who live in Isfahan city $(n=70)$. It is completely obvious that question number $18,14,17,5,2,16$ are the six first important parameters on sustainability of historical city. First rank goes to parking and traffic problem with the weight of 0.323025 ; the second rank is Pay attention for historical environment in new designs. Air and sound pollution with .4003 ranked third. Table 8 provides six of the most important parameters that affect on sustainability of historical city by their weight

\section{Conclusion}

The result showed that out of eighteen questions from sustainability of historic city, many people tend to emphasize the social side of sustainable development and environment part had less importance in public point of view. We suggested planners and politician should pay more attention to environment and economic aspects of sustainability in order to establish a balance between all three aspects of sustainable development and improve heritage awareness for now and next generation.

It seems that the main problem for historical cities in public point of view is traffic and parking space, and the problem coming through traffic congestion such as air and sound pollution. The second problem encounters a balance between new design and heritage area, developing the city infrastructure and economic profit for local residence. Regarding these problems the

Table1. The result of the questionnaire

\begin{tabular}{|l|l|l|l|l|l|}
\hline $\begin{array}{c}\text { No: of } \\
\text { question }\end{array}$ & $\begin{array}{c}\text { NI (Not } \\
\text { important) }\end{array}$ & $\begin{array}{c}\text { LI (Not } \\
\text { important) }\end{array}$ & $\begin{array}{c}\text { A } \\
\text { (Average) }\end{array}$ & $\begin{array}{c}\text { I (Not } \\
\text { important) }\end{array}$ & $\begin{array}{c}\text { VI (very } \\
\text { important) }\end{array}$ \\
\hline 1 & 9 & 11 & 15 & 26 & 9 \\
\hline 2 & 1 & 4 & 28 & 30 & 7 \\
\hline 3 & 2 & 8 & 30 & 20 & 10 \\
\hline 4 & 5 & 5 & 26 & 15 & 19 \\
\hline 5 & 4 & 6 & 38 & 15 & 6 \\
\hline 6 & 0 & 3 & 15 & 28 & 24 \\
\hline 7 & 3 & 7 & 11 & 22 & 27 \\
\hline 8 & 1 & 6 & 14 & 26 & 23 \\
\hline 9 & 4 & 7 & 9 & 22 & 26 \\
\hline 10 & 0 & 3 & 17 & 31 & 19 \\
\hline 11 & 6 & 9 & 23 & 17 & 15 \\
\hline 12 & 2 & 2 & 17 & 28 & 20 \\
\hline 13 & 4 & 7 & 22 & 26 & 9 \\
\hline 14 & 1 & 4 & 12 & 13 & 40 \\
\hline 15 & 2 & 3 & 20 & 28 & 17 \\
\hline 16 & 3 & 3 & 12 & 23 & 28 \\
\hline 17 & 1 & 0 & 18 & 15 & 36 \\
\hline 18 & 2 & 1 & 3 & 12 & 52 \\
\hline tage conservation in Iran" & & & & A.Assari \& E.Assari \\
Indian J.Sci.Technol.
\end{tabular}


Table 2. First process on the result of questionnaire by multiply each cell by itself and second process each cell should be divided to sqrt

\begin{tabular}{|l|l|l|l|l|l|}
\hline No: of question & NI (Not important) & LI (Not important) & A (Average) & I (Not important) & VI (very important) \\
\hline 1 & 5.36 & 5.01 & 2.64 & 6.97 & 0.78 \\
\hline 2 & 0.07 & 0.66 & 9.20 & 9.28 & 0.47 \\
\hline 3 & 0.26 & 2.65 & 10.56 & 4.12 & 0.96 \\
\hline 4 & 1.66 & 1.04 & 7.93 & 2.32 & 3.46 \\
\hline 5 & 1.06 & 1.49 & 16.94 & 2.32 & 0.35 \\
\hline 6 & 0.00 & 0.37 & 2.64 & 8.08 & 5.52 \\
\hline 7 & 0.60 & 2.03 & 1.42 & 4.99 & 6.99 \\
\hline 8 & 0.07 & 1.49 & 2.30 & 6.97 & 5.07 \\
\hline 9 & 1.06 & 2.03 & 0.95 & 4.99 & 6.48 \\
\hline 10 & 0.00 & 0.37 & 3.39 & 9.90 & 3.46 \\
\hline 11 & 2.38 & 3.35 & 6.21 & 2.98 & 2.16 \\
\hline 12 & 0.26 & 0.17 & 3.39 & 8.08 & 3.84 \\
\hline 13 & 1.06 & 2.03 & 5.68 & 6.97 & 0.78 \\
\hline 14 & 0.07 & 0.66 & 1.69 & 1.74 & 15.34 \\
\hline 15 & 0.26 & 0.37 & 4.69 & 8.08 & 2.77 \\
\hline 16 & 0.60 & 0.37 & 1.69 & 5.45 & 7.52 \\
\hline 17 & 0.07 & 0 & 3.80 & 2.32 & 12.43 \\
\hline 18 & 0.26 & 0.04141644 & 0.11 & 1.48 & 25.93 \\
\hline SQRT & 15.10 & 24.15 & 85.23 & 97.03 & 104.29 \\
\hline SQRT/SUM(SQRT) & 0.046 & 0.074 & 0.262 & 0.298 & 0.320 \\
\hline
\end{tabular}

Table 3. The matrix of multiply of Table 2 by matrix 3

\begin{tabular}{|c|c|c|c|c|c|}
\hline No: of question & NI (Not important) & LI (Not important) & A (Average) & I (Not important) & VI (very important) \\
\hline 1 & 0.248608 & 0.371406 & 0.690609 & 2.074889 & 0.248618 \\
\hline 2 & 0.003069 & 0.049111 & 2.40639 & 2.762427 & 0.150399 \\
\hline 3 & 0.012277 & 0.196446 & 2.762438 & 1.227745 & 0.306936 \\
\hline 4 & 0.076731 & 0.076737 & 2.074898 & 0.690607 & 1.108039 \\
\hline 5 & 0.049108 & 0.110501 & 4.432178 & 0.690607 & 0.110497 \\
\hline 6 & 0 & 0.027625 & 0.690609 & 2.40638 & 1.767951 \\
\hline 7 & 0.027623 & 0.150404 & 0.371394 & 1.485572 & 2.237563 \\
\hline 8 & 0.003069 & 0.110501 & 0.601598 & 2.074889 & 1.623691 \\
\hline 9 & 0.049108 & 0.150404 & 0.248619 & 1.485572 & 2.074887 \\
\hline 10 & 0 & 0.027625 & 0.887049 & 2.949658 & 1.108039 \\
\hline 11 & 0.110492 & 0.248627 & 1.623699 & 0.887046 & 0.690606 \\
\hline 12 & 0.012277 & 0.012278 & 0.887049 & 2.40638 & 1.227744 \\
\hline 13 & 0.049108 & 0.150404 & 1.485578 & 2.074889 & 0.248618 \\
\hline 14 & 0.003069 & 0.049111 & 0.44199 & 0.518722 & 4.910975 \\
\hline 15 & 0.012277 & 0.027625 & 1.22775 & 2.40638 & 0.887045 \\
\hline 16 & 0.027623 & 0.027625 & 0.44199 & 1.623693 & 2.406378 \\
\hline 17 & 0.003069 & 0 & 0.994478 & 0.690607 & 3.97789 \\
\hline 18 & 0.012277 & 0.003069 & 0.027624 & 0.441988 & 8.299548 \\
\hline
\end{tabular}

Following policies are recommended: a) Improvement in public transport system to reduce fuel consumption, traffic congestion and pollution. b) Improved transport system based on bio-energy and other eco-friendly energy. c) Improvement in traffic flow through proper maintenance of roads, updated traffic regulation and strict enforcement of prescribed standards d) Improvement of infra-structural facilities such as water supply, sewerage, solid waste disposal, energy recovery systems and transportation in an integrated manner
Table 4. max and min of each column in Table 3 that highlighted with red and blue color

\begin{tabular}{|l|l|l|l|l|l|}
\hline $\max A$ & 0.248608 & 0.371406 & 4.432178 & 2.949658 & 8.299548 \\
\hline $\min A$ & 0 & 0 & 0.027624 & 0.441988 & 0.110497 \\
\hline
\end{tabular}

Research article

CIndian Society for Education and Environment (iSee)
A.Assari \& E.Assari Indian J.Sci.Technol. 
Table 5. The forth step in TOPSIS method (it has five parts)-distance between max point and each point

\begin{tabular}{|c|c|c|c|c|c|}
\hline$(v i j-v j+)$ & $(v i j-j+)^{\wedge} 2$ & $(v i j-v j+)$ & $(v i j-v j+)^{\wedge} 2$ & $(v i j-v j+)$ & $(\mathrm{vij}-\mathrm{vj}+)^{\wedge} 2$ \\
\hline 0.0000 & 0.0000 & 0.0000 & 0.0000 & -3.7416 & 13.9993 \\
\hline-0.2455 & 0.0603 & -0.3223 & 0.1039 & -2.0258 & 4.1038 \\
\hline-0.2363 & 0.0559 & -0.1750 & 0.0306 & -1.6697 & 2.7880 \\
\hline-0.1719 & 0.0295 & -0.2947 & 0.0868 & -2.3573 & 5.5568 \\
\hline-0.1995 & 0.0398 & -0.2609 & 0.0681 & 0.0000 & 0.0000 \\
\hline-0.2486 & 0.0618 & -0.3438 & 0.1182 & -3.7416 & 13.9993 \\
\hline-0.2210 & 0.0488 & -0.2210 & 0.0488 & -4.0608 & 16.4900 \\
\hline-0.2455 & 0.0603 & -0.2609 & 0.0681 & -3.8306 & 14.6733 \\
\hline-0.1995 & 0.0398 & -0.2210 & 0.0488 & -4.1836 & 17.5022 \\
\hline-0.2486 & 0.0618 & -0.3438 & 0.1182 & -3.5451 & 12.5679 \\
\hline-0.1381 & 0.0191 & -0.1228 & 0.0151 & -2.8085 & 7.8876 \\
\hline-0.2363 & 0.0559 & -0.3591 & 0.1290 & -3.5451 & 12.5679 \\
\hline-0.1995 & 0.0398 & -0.2210 & 0.0488 & -2.9466 & 8.6825 \\
\hline-0.2455 & 0.0603 & -0.3223 & 0.1039 & -3.9902 & 15.9216 \\
\hline-0.2363 & 0.0559 & -0.3438 & 0.1182 & -3.2044 & 10.2684 \\
\hline-0.2210 & 0.0488 & -0.3438 & 0.1182 & -3.9902 & 15.9216 \\
\hline-0.2455 & 0.0603 & -0.3714 & 0.1379 & -3.4377 & 11.8178 \\
\hline-0.2363 & 0.0559 & -0.3683 & 0.1357 & -4.4046 & 19.4001 \\
\hline (vij-vj+) & $(v i j-v j+)^{\wedge} 2$ & $(v i j-v j+)$ & $(\mathrm{vij}-\mathrm{vj}+)^{\wedge} 2$ & SUM & SQRT \\
\hline-0.8748 & 0.7652 & -8.0509 & 64.8175 & 79.5820 & 8.9209 \\
\hline-0.1872 & 0.0351 & -8.1491 & 66.4086 & 70.7117 & 8.4090 \\
\hline-1.7219 & 2.9650 & -7.9926 & 63.8818 & 69.7213 & 8.3499 \\
\hline-2.2591 & 5.1033 & -7.1915 & 51.7178 & 62.4943 & 7.9053 \\
\hline-2.2591 & 5.1033 & -8.1891 & 67.0606 & 72.2717 & 8.5013 \\
\hline-0.5433 & 0.2952 & -6.5316 & 42.6618 & 57.1362 & 7.5589 \\
\hline-1.4641 & 2.1435 & -6.0620 & 36.7477 & 55.4789 & 7.4484 \\
\hline-0.8748 & 0.7652 & -6.6759 & 44.5671 & 60.1340 & 7.7546 \\
\hline-1.4641 & 2.1435 & -6.2247 & 38.7464 & 58.4808 & 7.6473 \\
\hline 0.0000 & 0.0000 & -7.1915 & 51.7178 & 64.4657 & 8.0291 \\
\hline-2.0626 & 4.2544 & -7.6089 & 57.8960 & 70.0721 & 8.3709 \\
\hline-0.5433 & 0.2952 & -7.0718 & 50.0104 & 63.0583 & 7.9409 \\
\hline-0.8748 & 0.7652 & -8.0509 & 64.8175 & 74.3538 & 8.6229 \\
\hline-2.4309 & 5.9094 & -3.3886 & 11.4824 & 33.4776 & 5.7860 \\
\hline-0.5433 & 0.2952 & -7.4125 & 54.9452 & 65.6827 & 8.1045 \\
\hline-1.3260 & 1.7582 & -5.8932 & 34.7295 & 52.5763 & 7.2509 \\
\hline-2.2591 & 5.1033 & -4.3217 & 18.6767 & 35.7961 & 5.9830 \\
\hline-2.5077 & 6.2884 & 0.0000 & 0.0000 & 25.8800 & 5.0872 \\
\hline
\end{tabular}

Vol. 5 No. 3 (Mar 2012)

ISSN: 0974- 6846

Table 6. The forth step in TOPSIS method (it has five parts)-distance between min point and each point

\begin{tabular}{|c|c|c|c|c|c|}
\hline (vij-vj-) & $(v i j-v j-)^{\wedge} 2$ & (vij-vj-) & $(v i j-v j-)^{\wedge} 2$ & (vij-vj-) & $(v i j-v j-)^{\wedge} 2$ \\
\hline 0.2486 & 0.0618 & 0.3714 & 0.1379 & 0.6630 & 0.4395 \\
\hline 0.0031 & 0.0000 & 0.0491 & 0.0024 & 2.3788 & 5.6585 \\
\hline 0.0123 & 0.0002 & 0.1964 & 0.0386 & 2.7348 & 7.4792 \\
\hline 0.0767 & 0.0059 & 0.0767 & 0.0059 & 2.0473 & 4.1913 \\
\hline 0.0491 & 0.0024 & 0.1105 & 0.0122 & 4.4046 & 19.4001 \\
\hline 0.0000 & 0.0000 & 0.0276 & 0.0008 & 0.6630 & 0.4395 \\
\hline 0.0276 & 0.0008 & 0.1504 & 0.0226 & 0.3438 & 0.1182 \\
\hline 0.0031 & 0.0000 & 0.1105 & 0.0122 & 0.5740 & 0.3294 \\
\hline 0.0491 & 0.0024 & 0.1504 & 0.0226 & 0.2210 & 0.0488 \\
\hline 0.0000 & 0.0000 & 0.0276 & 0.0008 & 0.8594 & 0.7386 \\
\hline 0.1105 & 0.0122 & 0.2486 & 0.0618 & 1.5961 & 2.5475 \\
\hline 0.0123 & 0.0002 & 0.0123 & 0.0002 & 0.8594 & 0.7386 \\
\hline 0.0491 & 0.0024 & 0.1504 & 0.0226 & 1.4580 & 2.1256 \\
\hline 0.0031 & 0.0000 & 0.0491 & 0.0024 & 0.4144 & 0.1717 \\
\hline 0.0123 & 0.0002 & 0.0276 & 0.0008 & 1.2001 & 1.4403 \\
\hline 0.0276 & 0.0008 & 0.0276 & 0.0008 & 0.4144 & 0.1717 \\
\hline 0.0031 & 0.0000 & 0.0000 & 0.0000 & 0.9669 & 0.9348 \\
\hline 0.0123 & 0.0002 & 0.0031 & 0.0000 & 0.0000 & 0.0000 \\
\hline (vij-vj-) & $($ vij-vj-)^2 & (vij-vj-) & $(v i j-v j-)^{\wedge} 2$ & SUM & SQRT \\
\hline 1.6329 & 2.6664 & 0.1381 & 0.0191 & 3.3247 & 1.8234 \\
\hline 2.3204 & 5.3844 & 0.0399 & 0.0016 & 11.0470 & 3.3237 \\
\hline 0.7858 & 0.6174 & 0.1964 & 0.0386 & 8.1739 & 2.8590 \\
\hline 0.2486 & 0.0618 & 0.9975 & 0.9951 & 5.2600 & 2.2935 \\
\hline 0.2486 & 0.0618 & 0.0000 & 0.0000 & 19.4765 & 4.4132 \\
\hline 1.9644 & 3.8588 & 1.6575 & 2.7472 & 7.0463 & 2.6545 \\
\hline 1.0436 & 1.0891 & 2.1271 & 4.5244 & 5.7550 & 2.3990 \\
\hline 1.6329 & 2.6664 & 1.5132 & 2.2898 & 5.2978 & 2.3017 \\
\hline 1.0436 & 1.0891 & 1.9644 & 3.8588 & 5.0218 & 2.2409 \\
\hline 2.5077 & 6.2884 & 0.9975 & 0.9951 & 8.0229 & 2.8325 \\
\hline 0.4451 & 0.1981 & 0.5801 & 0.3365 & 3.1561 & 1.7765 \\
\hline 1.9644 & 3.8588 & 1.1172 & 1.2482 & 5.8460 & 2.4178 \\
\hline 1.6329 & 2.6664 & 0.1381 & 0.0191 & 4.8361 & 2.1991 \\
\hline 0.0767 & 0.0059 & 4.8005 & 23.0446 & 23.2246 & 4.8192 \\
\hline 1.9644 & 3.8588 & 0.7765 & 0.6030 & 5.9031 & 2.4296 \\
\hline 1.1817 & 1.3964 & 2.2959 & 5.2711 & 6.8407 & 2.6155 \\
\hline 0.2486 & 0.0618 & 3.8674 & 14.9567 & 15.9534 & 3.9942 \\
\hline 0.0000 & 0.0000 & 8.1891 & 67.0605 & 67.0607 & 8.1891 \\
\hline
\end{tabular}

Table 7. shows "cli+" that means distance between ai and ideal solution

\begin{tabular}{|c|c|c|}
\hline No: of question & $($ di-+di+) & Cli \\
\hline 1 & 10.7443 & 0.1697 \\
\hline 2 & 11.7327 & 0.2833 \\
\hline 3 & 11.2089 & 0.2551 \\
\hline 4 & 10.1988 & 0.2249 \\
\hline 5 & 12.9145 & 0.3417 \\
\hline 6 & 10.2133 & 0.2599 \\
\hline 7 & 9.8474 & 0.2436 \\
\hline 8 & 10.0563 & 0.2289 \\
\hline 9 & 9.8882 & 0.2266 \\
\hline 10 & 10.8615 & 0.2608 \\
\hline 11 & 10.1474 & 0.1751 \\
\hline 12 & 10.3588 & 0.2334 \\
\hline 13 & 10.8220 & 0.2032 \\
\hline 14 & 10.6052 & 0.4544 \\
\hline 15 & 10.5341 & 0.2306 \\
\hline 16 & 9.8664 & 0.2651 \\
\hline 17 & 9.9771 & 0.4003 \\
\hline 18 & 13.2763 & 0.6168 \\
\hline
\end{tabular}

\begin{tabular}{|c|c|c|}
\hline SORT $\mathrm{Cli}_{\mathrm{i}}$ & Raked by weight & Number of question \\
\hline 0.1697 & 1 & 18 \\
\hline 0.1751 & 11 & 17 \\
\hline 0.2032 & $\overline{13}$ & 16 \\
\hline 0.2249 & $\overline{4}$ & 15 \\
\hline 0.2266 & $\underline{\underline{9}}$ & 14 \\
\hline 0.2289 & $\underline{8}$ & 13 \\
\hline 0.2306 & 15 & 12 \\
\hline 0.2334 & $\overline{12}$ & 11 \\
\hline 0.2436 & $\overline{7}$ & 10 \\
\hline 0.2551 & $\underline{3}$ & 9 \\
\hline 0.2599 & $\underline{6}$ & 8 \\
\hline 0.2608 & 10 & 7 \\
\hline 0.2651 & $\underline{16}$ & 6 \\
\hline 0.2833 & $\overline{2}$ & 5 \\
\hline 0.3417 & 5 & 4 \\
\hline 0.4003 & $\underline{17}$ & 3 \\
\hline 0.4544 & 14 & 2 \\
\hline 0.6168 & 18 & 1 \\
\hline
\end{tabular}


Table 8. Six of most important parameters that affect on sustainability of historical city by their weight

\begin{tabular}{|l|c|c|}
\hline \multicolumn{1}{|c|}{ Parameters } & Weight & Rank \\
\hline parking and traffic & 0.6168 & 1 \\
\hline historical environment in new design & 0.4544 & 2 \\
\hline air and sound pollution & 0.4003 & 3 \\
\hline developing in heritage area & 0.3417 & 4 \\
\hline economic profit for local residence & 0.2833 & 5 \\
\hline city infrastructure in heritage area & 0.2651 & 6 \\
\hline
\end{tabular}

\section{References}

1. Abdi MA and Namin SM (2008) Spatial planning as an approach to achieve sustainable development in historic cities. World Acad.Sci. Engg. \& Technol. pp: 215-220.

2. Asgharpou MJ (1999) Multiple criteria decision making. Tehran Univ. Press, Tehran.

3. Assari, A., \& Assari, E. (2012). Urban spirit and heritage conservation problems: case study Isfahan city in Iran. Journal of American Science , 8 (1), 202109.

4. Assari, A., Mahesh, T.M, \& Assari, E (2012). Conservation of historic urban core in traditional Islamic culture: case study of Isfahan city. Indian Journal of Science and Technology , 5 (1), 19691976.

5. Assari, a., Mahesh, T. M., Emtehani, M. R., \& Assari, E. (2011). comparative sustainability of bazaar in iranian traditional cities: case studies in isfahan and tabriz. International Journal on Technical and Physical Problems of Engineering (IJTPE) , 3 (9), 1824.

6. Azman N, Abdul Halim S and Komoo I (2010) Public education in heritage conservation for geopark community: A case for Langkawi Global Geopark. Proc. Social \& Behavioral Sci. Esevier . pp: 504-511.

7. Ball $S$ and Korukoğlu $S$ (2009) Operating system selection using fuzzy ahp and topsis methods. Math. \& Computational Appl.14 (2), 119-130.

8. Benitez J Martin J and Roman C (2007) Using fuzzy number for measuring quality of service in the hotel industry. Tourism Manage. 28 (2), 544-555.

9. Doratli NH (2004) An analytical methodology for revitalization strategies in historic urban quarters: a case study of the Walled City of Nicosia, North Cyprus. Cities , 21 (4), 329-348.

10. European Charter of the Architectural Heritage. (1975). available online: http://www.icomos.org/ docs/euroch_e.html. Amsterdam: Adopted by the Council of Europe.

11. Fisher $F$ (2001) Building bridges between citizens and local governments through participatory planning and managing conflicts and differencesPart 1:Concept and strategies. Nairobi: UN-HABITAT. 